\section{Heidegger and socio-ontology: A sociological reading}

\author{
Sebastian Kohl \\ Max Planck Institute for the Study of Societies, Germany

\section{Patrik Aspers} \\ Uppsala University, Sweden
}

Journal of Classical Sociology 13(4) 487-508 (C) The Author(s) 2013

Reprints and permissions: sagepub.co.uk/journalsPermissions.nav DOI: I 0.1 I77//468795X13480647 jcs.sagepub.com

(SAGE

\begin{abstract}
This paper uses the work and employs the tools of the German philosopher Martin Heidegger to attempt to improve sociology. Heidegger's thinking is employed primarily to undo a paradox of sociology. Sociology focuses on the social, but starts with the assumption of essentially nonsocial egos that somehow generate a social world. This 'egologism' has caused sociology to occupy itself with a number of pseudo-problems. We argue that Heidegger develops what we call a 'socio-ontological' approach, which means that human beings are always already social and dwell originarily in a social world. To present this 'social foundation for sociology' is the contribution of this paper.
\end{abstract}

\title{
Keywords
}

Egologism critique, Heidegger, phenomenology, pseudo-problems, social ontology

Contemporary sociology practices a thorough methodological individualism and defends more or less explicitly its ontological counterpart. This is noticeable in rational choice and game theory approaches, as well as in survey-based research. Unexpectedly, as we show below, it even made its way from the discipline's classics into relational sociology. ${ }^{1}$ This observation is surprising given that one could expect sociology, unlike psychology, to not presume individualism. ${ }^{2}$ This current state of affairs is problematic considering that the world we live in is not one of atomized individuals. Thus, individualist approaches seem to run into pseudo-problems when analyzing day-to-day cooperation.

This article, in a first step, has the modest goal to make sociologists more conscious of the problematic non-social foundation of sociology. It does so by sketching the history

\footnotetext{
Corresponding author:

Patrik Aspers, Department of Sociology, Uppsala University, Box 624, 75I 26 Uppsala, Sweden.

Email: patrik.aspers@soc.uu.se
} 
of this problem. Our argument is that, despite its etymological root, sociology lacks a truly social foundation. Its present foundation, in contrast, can be traced to Cartesian epistemology (see Schmid, 2009: 38ff.) and its central problem of how knowledge of the external world is obtained. The epistemological question is raised based on the presumption that each atomistic ego must pose this question. What is generally called 'social' is only a derivative of the epistemological-egological starting point. This assumption has cast an epistemological-egological spell on sociology. The atomistic situation of the cognizing ego was the starting point of social thinking, out of which sociology grew. An atomistic epistemology seems to be at the origin of an atomistic social ontology that has been pervading the social sciences. ${ }^{3}$

In a second step, the article informs sociologists about a possible non-individualist alternative that can be found in Martin Heidegger's early work, rarely discussed by sociologists. Following a central aim of this journal, we thus offer sociologists access to what is to them likely to be a relatively unknown philosophical classic. ${ }^{4}$ Classical sociologists, such as Weber, Durkheim, and Simmel, saw the world, including the individuals - or, put differently, atoms (egos) - in it, as given, although they all defined their own 'objects' of inquiry. ${ }^{5}$ The value of these classical thinkers has been shown several times in this journal, but the role of Heidegger has not been prominent (though see Swedberg, 2011). Considering the lasting influence that Husserl's phenomenology, via Schütz, made on parts of sociology, one might wonder what potential sociology forgoes by ignoring Heidegger.

But why, above that, should sociologists care at all about ontology and about Heidegger's position on it? One reason is that ontological questions on what there is can hardly be separated from epistemological and methodological questions (on how to approach what there is). And these latter questions do indeed concern sociologists. If - to give an example - one is truly convinced of a non-individualist position in ontology, one is likely to see little sense in pursuing laboratory experiments with isolated subjects when trying to explain social phenomena.

Another reason to have a look at Heidegger is that, historically, sociology has often been inspired, to say the least, by importing ideas from other disciplines or by questioning its very origins. Sociologists have tried to improve their trade by going back to its roots, or by reinterpreting its tradition (for example, Habermas, 1984 [1981], 1987 [1981]; Joas, 1997a [1992], 1997b; Parsons, 1968 [1937]). There is also the strategy of importing ideas from neighboring disciplines: for example, the decision theory of rational choice from economics, which is used as an assumption about how people behave outside the economic realm. Articles that attempt to 'bring something into sociology' are a further indication of the circulation of ideas, rather than of radical revision.

Sociologists have either remained in the precinct of sociology or, at most, they have looked for inspiration from other social or natural science disciplines. None of these strategies make it possible to address the foundations and default assumptions of sociology or any of the other social sciences, since the same foundational assumptions remain the starting point.

By turning to Heidegger, and developing sociological theory with the help of essentially non-sociological tools, we suggest a way to free sociology from its epistemological-egological spell. We argue that Heidegger provides what is missing in sociology and 
the social sciences in general: an ontology based on a person who is in the world, comprising among other things fellow persons. This approach based on Heidegger's work we call socio-ontology. It is our claim that the assumption of 'ontological' egology (egologism) should be replaced by a socio-ontological base. The article points towards additional potential avenues of research for sociologists interested in Heidegger, such as his discussion of language, action, and technology.

The article is organized as follows. To use the work of a philosopher to address sociological problems calls for some initial reflection, and we begin by discussing our methodology, which is different from traditional sociological theorizing. We then discuss why it is problematic that the social sciences are based on non-social assumptions, and we show how we shall understand this egological position. In the third section, we turn to Heidegger, beginning with his sociological reception. Next we present and discuss Heidegger's ideas: we mainly describe how he comes to reject an atomistic starting point in ontology. In the concluding section, we point towards further research that sociologists inspired by Heidegger might undertake.

\section{The phenomenological-hermeneutic method}

Our goal, in short, is to help sociology see what it cannot see when using its own tools. Sociologists either have based their reasoning on premises that are taken for granted, or have used methodologies to investigate these premises which rely on those same premises. Besides adopting a method inspired by Heidegger, we also present some of Heidegger's ideas. This section thus has a double function.

Our study zooms in on the most basic assumption of any research approach, namely the ontological: in other words, the domain in which what the world of study consists of is discussed. Since the assumption we want to critically analyze is so deeply entrenched within the sociological tradition, we suggest using tools and methodologies taken partly from another discipline, namely philosophy. Our method is phenomenological-hermeneutic (Heidegger, 2001b [1927]). It is not a method, like interviewing, with a set of rules, an idea rejected explicitly by Gadamer (1990 [1960], 1993), but nonetheless a way of gaining understanding. ${ }^{6}$ The hermeneutic method reflects on the most basic questions, and the most taken-for-granted principles of scientific work, including logic and its principles (Heidegger, 1997 [1957]). ${ }^{7}$ We follow this hermeneutic-phenomenological method and interpret specific issues within the framework of our knowledge of the whole of the 'sociological perspective.' Needless to say, our horizon of relevance (Schütz, 1996: 198) is 'the social. ${ }^{8}$ Our interpretation and reading are affected, but not determined, by sociology.

More specifically, we use Heidegger's phenomenological-hermeneutic method, which can be divided into three steps: reduction, deconstruction, and construction. Reduction implies that we go back to the question of being; deconstruction refers to the starting point of the analysis (Heidegger, 1975: 28-31) - that is, the tradition in which the taken-for-granted views have been formed; and construction refers to the study of being. Deconstruction does not mean to destroy, but to take apart (Abbau). Heidegger wants to deconstruct not ontology itself, but, rather, historically produced doctrines of being (2001b [1927]: 22-23); deconstruction is a concrete way of doing this (Heidegger, 1994: 
118). ${ }^{9}$ Sociology, in sum, has not been able to deconstruct its own foundation and, to be clear, the ontology on which its rests. We argue that this can be done using the phenomenological approach.

According to the phenomenological-hermeneutic approach, an interpretation starts with our conception (preconception) of our object of interest in order to get to the phenomenon. Heidegger argues that understanding implies a presupposition; the way a question is formulated always builds on a pre-understanding, a form of knowledge which frames the expected answers (Heidegger, 2001b [1927]: 5). Understanding is a process of interpretation; by gradually refining the questions posed in light of the answers generated, revising the first partial understanding and presuppositions, a person approaches coherence between parts and the whole. This method, often narrowly associated with the analysis of texts, is a general problem-solving strategy for Heidegger and, most interestingly, one which applies to the social world as well. ${ }^{10}$

We should, consequently, start with what we 'know,' but the aim is to question this historically produced 'knowledge,' which in our case is the sociological tradition. For Heidegger, Dasein, a special conception of subjects in the world, is the center of the analysis. To analyze 'the world' without starting with Dasein, in Heidegger's view, is nonsense. Heidegger sees Dasein as both part of the world and an initiator of research. This is a radically different strategy compared to what we know from sociology, which essentially takes the world for granted and sees it as an object of study. We will then see that the ontology of the world cannot be separated from the ontology of Dasein and, of special interest for our article, that Dasein is inherently 'social.'

Not only do we follow Heidegger regarding method, we also analyze the 'social dimension' in his work. ${ }^{11}$ We will analyze only a small part of his texts, concentrating on his magnum opus Sein und Zeit (Heidegger, 2001b [1927]) (Being and Time), and some of the other texts in which he treats sociologically relevant issues. ${ }^{12}$

\section{Epistemological and egological roots of the social sciences}

Christian and Cartesian streams of thought have been fused over time into the idea of a reflexive and knowing subject destined to investigate a world given by God. This was made explicit in the works of Descartes (Steel, 2004). A corresponding idea is that of individualism (Udehn, 2002), which early political economists propagated (Hirschman, 1986 [1982]). The forerunners of sociological thinking, like the social contract theorists, Hobbes, Locke, and Rousseau, were living in an era of rising individualism (Calhoun et al., 2007: 6). Early sociologists, who carved out their discipline on the basis of a critique of economics, essentially took over the idea of atomistic actors who become social only when they interact with others or when they orient themselves towards others. Since we cannot trace these ideas throughout history, we will look more closely at a few representative social science approaches to make our point.

It is perhaps obvious that approaches such as economics and, more generally, rational choice theory start with the egological assumption (Olson, 1971 [1965]) of atomistic actors, and it is not difficult to trace an egological starting point to economics and its 
utilitarian and contractualist roots. Economists view actors and their preferences as essentially unaffected by each other's preferences (Becker and Murphy, 2000).

To make our point clear about the shared egological assumptions of sociology, we will here look at only one paradigmatic example: the father of sociology, Max Weber. Weber's idea of sociology refers to actions that are oriented to others, but this is merely a subcategory of action. He says:

We shall speak of 'action' insofar as the acting individual attaches a subjective meaning to his behavior - be it overt or covert, omission or acquiescence. Action is 'social' insofar as its subjective meaning takes into account the behavior of others and is thereby oriented to its course.

(Weber, 1978 [1921-2]: 4)

The most important sentence for our purpose is the last one. Action is a primordial notion in Weberian sociology (see Swedberg, 1998), but only some actions, representing a sub-category, are social. ${ }^{13}$ It follows from Weber's texts and the problems and definitions with which he works that he starts with egos, which only sometimes are 'social,' given their essentially non-social character. Weber took over core ideas about economic man and the idea of methodological individualism from economics, although he did not subscribe to the idea of marginal utility (Swedberg, 1998: 22-28). In fact, it supports our interpretation that the conceptualization of man in sociology is derived from economics.

We do not want to single out Weber for criticism; instead, we take him to represent what we see as an underlying assumption of almost all sociologists, namely the egological foundation, which is also reflected in the subjectivism-objectivism discussion (Bourdieu, 1987: 1; 1990 [1980]: 25; Giddens, 1984: xx). It is not difficult to trace the epistemological-egological foundation in important sociological works, such as those of Parsons, Bourdieu, Giddens, Habermas, Berger and Luckmann, Schütz, and many more (for example, Giddens, 1984; Parsons, 1968 [1937]; Schütz, 1976 [1932]).

The egological idea is not only to be found in the European tradition of sociology, but is also present in the works of Mead (Malhotra, 1987) and in American pragmatism, in which we find the roots of much of US sociology. The egological approach is noticeable already in the works of Peirce, who sees the epistemological subjective-objective problem as fundamental. More recent developments that have explicitly tried to rethink what the social means, such as network theory (Granovetter, 1985) and the literature reviewed under the heading of relational sociology (Emirbayer, 1997), are still, at their root, egological at the level of ontology.

To substantiate these claims, since we cannot review the entire sociological literature, our strategy is to pick out the self-proclaimed most relational approach in US sociology, namely relational sociology, to show that even in this school non-social roots prevail. What are the assumptions of relational sociology regarding man and his constitution? Although there may be differences among relational theories, we will here look more closely at the most prominent thinker of the relational sociological school, Harrison White. White has developed a theory of social disciplines at the middle-range level (White, 1992: xii). He sometimes refers to them as 'molecules,' which are described as 
'self-reproducing structural contexts which sustain identities' (White, 1992: 22). Identities emerge as a result of interaction in the social molecules, or, put differently: 'Identities spring up out of efforts at control in turbulent contexts' (White, 2008: 1). Identities try to control themselves in relation to the environment, which is made up mainly of other identities. An identity is defined as 'any source of action not explicable from biophysical regularities, and to which observers can attribute meaning' (White, 1992: 6).

Identity, rather than persons (White, 1992: 24), is the starting point of the analysis, which can never be analyzed separately from its environment. White argues that persons come into 'existence and are formed as the result of overlaps among identities from distinct network populations' (2008: 129). Identities evolve in social interaction; it is here that the most central idea of 'relational sociology' appears in White's thinking. There is an essential relation - the tie - that is constitutive of identities (White, 2008: 20-36).

Notions such as network and tie clearly reflect a relational stance, but we know less about the analytic starting point and the ontological assumptions of this approach. It is at the ontological level that we have to pose the question of whether or not relational sociology represents an egological approach. The following quotation brings us closer to an answer: '... without footing, identities would jump around in a social space without meaning, thus without communication' (White, 2008: 1). White, apparently, claims that footing is the result of control projects on the part of identities. It is assumed that somehow the 'non-social identities' - although this is a contradiction in terms - start to interact, and out of this, some order is generated that creates social contingencies and relations and thereby stabilizes these identities. But before we can speak of identities, there are egos jumping around, and only in a process of interaction do they become social (identities). What does this presuppose? White analyzes, 'for simplicity,' 'identities as tagged to individual human beings' (2008: 10). It appears as if something is tied to the preexisting atomistic units called humans. When these come together, we can speak of the 'social. ${ }^{14}$ Our finding, thus, is that White's approach, too, is based on egological assumptions, none of which is discussed. We take this as evidence for our more general claim that the egological approach applies to almost all, if not all, sociologists.

\section{The philosophical root: Husserl's egology}

We have now given examples of the egological approach, and have shown that this is the assumption even of central sociological approaches. These approaches pose an epistemological question: What is the world like, given the assumed ontology of egos? But what, in more detail, is this egological approach? In this section we do not introduce a new argument, but make a philosophical tour to clarify the egologism of which we find only weak or tacit traces in sociology.

To clearly show what egologism means, we will highlight the position of Edmund Husserl, who made the Cartesian idea of egology explicit. Husserl also serves as the point of reference for Heidegger and Schütz; more indirectly, several thinkers have been influenced by Husserl's views. ${ }^{15}$ Husserl wants to obtain absolute knowledge by identifying a foundation. This is, in brief, achieved by a transcendental reduction that brackets our ordinary lifeworld - that is, the world in which we live and that is completely taken 
for granted. This reduction is performed in the first person. Phenomenology, according to Husserl, is an activity of egos in solitude. Husserl, however, also outlines a transcendental 'community' of egos. The social problem - or the problem of intersubjectivity is, according to Husserl, a derivative question in relation to the Cartesian question of how to obtain knowledge of the external world. To Husserl, social communities are simply 'personalities of a higher order' (1960 [1931]: 132). ${ }^{16}$ The following is a very clear statement of what we have termed egology and it is clear what Husserl had in mind:

This universal concrete ontology (or universal and concrete theory of science - this concrete logic of being) [transcendental phenomenology] would therefore intrinsically be the first universe of science grounded on an absolute foundation. With regard to order, the intrinsically first of the philosophical disciplines would be 'solipsistically' reduced 'egology', the egology of the primordially reduced ego. Then only would come intersubjective phenomenology, which is founded on that discipline.

(1960 [1931]: 155)

In other words, Husserl's egological approach assumes subjects (egos) who somehow reach out and try to understand everything in their environment, including others' 'social lives.' That Husserl's starting point is non-social is thus clear, especially in his fifth Cartesian Meditation (Husserl, 1960 [1931]), which, contrary to Husserl's ambition, shows that his approach remains within the boundaries of the ego and its transcendental world. ${ }^{17}$ Husserl's approach, to conclude, is 'first of all monadic, and then intermonadic' (1960 [1931]: 156). ${ }^{18}$

This division of ego, on the one hand, and the world with its things - including alter(s) - on the other, is profound, and has largely become taken for granted. Heidegger shows how deeply entrenched this notion had become by admitting that even he took it as starting point at one stage. He is, however, clear about this mistake, as can be seen in this quote from a lecture in 1925: 'This idea is fundamentally wrong' ('Die Sache ist aber grundfalsch') (Heidegger, 1979: 333).

We have now identified the egological and epistemological roots of sociology, as well as the ontological assumptions, and have shown how taken for granted they have become. This is also the second step of the phenomenological-hermeneutical method: the destruction of the historically produced doctrine of being. Heidegger's phenomenological-hermeneutical approach aims at uncovering what is on the surface to finally get a better understanding of the phenomena. As we have said, our attempt to present an alternative to the present position draws on Heidegger, and since he is little known in sociology, we shall briefly introduce his work before using it to help to direct our key question of egologism and a potential social ontology.

\section{Heidegger and sociology: Being at a distance}

In this section, we briefly review Heidegger's reception among sociologists. We will also discuss Heidegger's position in relation to pragmatism, since it represents another potential basis for a truly social foundation of the social sciences - especially since it could be argued that Heidegger's work only represents a detour to pragmatism. ${ }^{19}$ 
Schmid (2005: 246ff., 274) and Weiss (2001) comment on how Heidegger is viewed by sociologists. The general view is that he is not well received in the social sciences (Schmid, 2003: 481). A first reaction to Heidegger's sociologically relevant work was expressed by his then student Herbert Marcuse, who pretty much set the stage for a standard critique: the lack of a dimension of socialization in Dasein, possibly owing to the fact that Heidegger, much like Husserl, appears to talk in the intrinsically subjectivist language of intentionality (Theunissen, 1965: 156ff.). It is true that Heidegger presented that idea of a historically situated subject and his analysis of everyday Dasein can be read as overcoming the intentionalist divide between the subject and its outer world. However, when it comes to the public sphere of norms and conventions in Being and Time, the 'Man' is considered by Heidegger to be a somewhat deficient ('inauthentic') state of the subject. Turning away from the public sphere is the first step in ascending to the authentic (eigentlich) state of Dasein. ${ }^{20}$ The critique that Heidegger lacks an idea of socialization can, however, also be seen in the light of egologism. Socialization is often based on the idea that a naturally existing non-social being gradually becomes social; Heidegger's point is that Dasein is inherently or 'always already' social, and thus that socialization is merely one mode of social relations, while the 'absence' of proper socialization is another.

A second reaction comes from the philosophy of (social) science. Heidegger, more than any other German philosopher, is associated with the logical positivists' most loathed enemy: metaphysics. According to Carnap's nominal definition of sense or meaning, most of Heidegger's thought just does not make sense because it cannot be empirically controlled; nor does it fit into a logical analysis of language (Carnap, 1931). ${ }^{21}$ Heidegger's approach, demanding ever more reflection on what is already given, may even impede sociological research, as the positivist sociologist René König argued (see Schmid, 2003: 484). Close to this camp of criticism one also finds Adorno and, more recently, Bourdieu. Both attack Heidegger's way of doing philosophy by referring to an ever more profound 'sociological' level in order to criticize what they regard as shallow existing approaches which fail to acknowledge this new level. Whereas for Adorno (1992) Heidegger's 'jargon' only hints at mere nominalistic discussions pretending to a false ahistoricity, Bourdieu (1991 [1988]), in terms of the sociology of science, assimilates Heidegger's thought to the general academic field in the 1920s and 1930s and Heidegger's ambition to succeed in this environment. Another rather psychological approach claims that his personal situation explains what he wrote (Fischer, 2008). Collins (1998) and Bourdieu are the two best known sociologists who have discussed Heidegger. In both cases, however, the discussion is focused on the social conditions in which Heidegger wrote as an explanation of his work. We claim that these approaches to Heidegger's work, which are often critical, essentially bracket what he says, thereby missing the point he is making, namely that this form of 'scientism' takes its own foundation for granted and lacks tools to reflect on and analyze this. It is, in our view, thus not Bourdieu but Heidegger who offers tools for reflecting on the most profound assumptions, on which all theories - including Bourdieu's - are based. ${ }^{22}$ Moreover, discussions of social ontology are much more accepted these days than at the time of the sometimes overstretched metaphysical doubts in the 1930s (Walsh and Giulianotti, 2007). 
Finally, a third reaction to Heidegger does not share an in-principle rejection of Heidegger, and acknowledges his work, yet without truly making use of it. Some sociologists, such as the phenomenologist Schütz and his students Berger and Luckmann, have shown (limited) interest in Heidegger's thought because they think of him as being involved in a different or parallel (transcendental) project. ${ }^{23}$ This is somewhat surprising since they share the same phenomenological roots. Much to the contrary, other sociologists, such as early Bourdieu ${ }^{24}$ and, above all, Giddens, praise Heidegger as an important source of their work. This, however, is hardly ever spelled out in the works themselves. No real effort is made to interpret the original source, nor is it always clear to what extent the reference to Heidegger is more than an allusion to or based on misunderstandings of his ideas. $^{25}$

The idea that Heidegger is merely rephrasing what is already present in American pragmatism (Guignon, 2003) is a different form of critique that should be acknowledged. It is likely that Heidegger was exposed to pragmatism through Emil Lask (Dreyfus, 1991: 6), but we cannot know to what extent, or if so, with what consequence. Hans Joas (1993: 103-106) speaks of a 'Hidden Pragmatism' in the works of Heidegger (Robbins, 2002), but the direct evidence is weak. Although there are indications that Heidegger was exposed to the ideas of William James, it is also clear that there was an autonomous development of 'pragmatic motives' in Germany. To Heidegger, Greek philosophy, and most notably Aristotle, is a key source that points at the praxis orientation, which is at least as central as the action orientation of pragmatism. Joas (1993), however, argues that Heidegger's work is a clear conceptualization of pragmatism, but is Heidegger then merely copying what American pragmatic thinkers had already done?

Our view is that, although there are some similarities, the American pragmatists are not analyzing the ontological level; theirs is more of an epistemological approach, which deals with the ontic (in Heidegger's vocabulary) assumption of reality (Aikin, 2006). ${ }^{26}$ Heidegger is aiming at ontology, and this is what we see as his novel idea, from which the social sciences can benefit. This difference, on which we claim that Heidegger's unique contribution is based, is not discussed by Joas.

One exception to the neglect of Heidegger among sociologists is Weiss (2001, 2005), who argues that sociologists have criticized Heidegger (often on normative grounds), sometimes excerpting individual concepts and making 'associative use' of them (but without connection to Heidegger's larger context), but most have just neglected him. Aspers has made use of Heidegger to develop both theoretical notions and empirical ideas $(2009,2010 \mathrm{~b})$. These are of course not the only sociologists who have made use of Heidegger. Foucault has employed Heidegger to do his archeological studies (Gutting, 2003), and is reported to have said: 'Heidegger has always been for me the essential philosopher' (cited in Sluga, 2003: 211). Foucault, however, never wrote on Heidegger. In contrast to what most sociologists have done - namely to interpret Heidegger's work using the tools of sociology - our strategy, as we have indicated, is different. We use Heidegger's tools to work on the very question of 'the social' and 'sociology.' Not surprisingly, we stand closer to Dreyfus (1991) - who indeed has made great progress in showing the relevance of Heidegger for social scientists - than to any of the sociologists who allude to Heidegger. It is now time to turn to Heidegger's thought. 


\section{Heideggerian thought}

What, then, are the tools that Heidegger uses? In this section, we want to show how the Heideggerian approach is interesting for sociologists in constructing a social ontology. Our ambition is to make his sometimes dispersed thoughts on these themes available to sociologists. There are yet other themes that are sociologically relevant, and which can be discussed in future studies on Heidegger and sociology, such as his views on 'care' ('Sorge'), action, and technology.

\section{The critique of the isolated epistemological subject}

We now turn to Heidegger, first to try to understand his critique of philosophy, which also affects the empirical sciences, and then to see what solutions he offers. Heidegger's project concerns the grounding of being. In order to address this issue, we shall make use of another of his methodological ideas, namely reduction. Probably no other philosopher has centered his thinking on a single question to the same extent as Heidegger. Being and Time is the first major exposition of the Heideggerian project, although it is clear from his seminars that he had already been working on these issues for many years. In Being and Time, Heidegger proposes a general outline of how to approach 'the question of the meaning of being.' His idea is first to ask about what grounds the being of (human) beings (Part I), then, in the never completed Part II, he wanted to inquire into the foundations of being tout court.

Heidegger's methodological decision to start with our everyday understanding of being is remarkable. ${ }^{27}$ Although it has made its way into philosophy, it is not yet used by sociologists. What else should be the starting point of an inquiry than the everyday understandings people themselves hold about their world? The most obvious mistake, which Heidegger strongly criticized, would be for a researcher to convert his or her theoretical models into an ontology of everyday social life. However, this, it could be argued, is what much of sociology - and, even more so, economics - has done, thereby detaching itself from the ordinary lifeworld. One might think here about rational expectation economists supposing that their objects of study behave as epistemic peers of economists. In other words, sociology has studied a world with a presumed, but never properly examined, ontological setup. In Heidegger's vocabulary, this presumed foundation is 'ontic' (that is, concerned with entities rather than with being itself).

Heidegger takes this unquestioned assumption of the ontology of everydayness as a starting question. The mistake is, as we indicated above, fundamentally philosophical, and mostly due to the fact that modern philosophy has centered mainly on epistemological questions related to a cognitive subject. All kinds of questions have thus been asked about how a subject could generate and hold true representations of objects, including other egos - alter egos - existing in a distinct way in the external world.

Against this leap from nowhere into the thinking 'I' with an assumed world, Heidegger argues that epistemological theories, whether they be true or false, do not tackle the hidden assumption that both the cognitive subject and the objects of its representation are parts of the same world. This is the self-evident starting point for Heidegger. 
Heidegger's philosophy, consequently, points to the implicit assumptions of opposing approaches. However, his critique of the epistemological tradition goes further. According to Heidegger, the epistemological tradition not only remained silent about the ontological question; even worse, it mistakenly converted the epistemological constellation of Cartesian subject and external world into a taken-for-granted ontology. In other words, the epistemological problem of uniting a representation with what is represented reappears as an ontologically rooted separation between subject and object, or, more generally, between subject and world. What started out as an epistemological thought experiment by Descartes to make use of methodological doubt turned into a widely shared assumption about isolated cognitive subjects separated from the world.

It is the epistemological-ontological way of thinking that Heidegger confronts when exemplifying 'being-in-the-world' in terms of a simple craftsman in his workshop, or man essentially related to fellow men. Heidegger's own thesis about the 'cognitive subject' - a notion which he profoundly rejects - and the world is diametrically opposed to the Cartesian view: Dasein or 'being-there,' an everyday German word for 'existence,' is what Heidegger substitutes for the traditional philosophical 'subject' and is essentially 'in the world': only against this background is it even possible to think about a worldisolated subject, as Descartes does. Put differently, the problems of isolation and of being alone are derived from being together, not the other way around.

To justify this 'first principle,' Heidegger makes use of an understanding of truth which he derives from Greek antiquity, which suggests that truth is not found in sentences that correspond to facts, but is already there in the immediate, pre-ontological perception of the everyday world. ${ }^{28}$ Heidegger builds on the intuition that we fundamentally do not doubt the world, nor are we hopelessly separated from it. Therefore, he suggests, without offering further arguments, to fundamentally replace the strange epistemology-inherited ontology. We already know that we are being-in-the-world, from our everyday-life experience. ${ }^{29}$

But the story of the Cartesian divide between subject and world - res cogitans and res extensa - does not stop there. Besides this epistemological divide between a single epistemic subject and its external world, Heidegger discovers a parallel line of thought emanating from Descartes that has become taken for granted in social philosophy. Our world is not only populated by things we already know about or that we have yet to discover. Other Daseins make up our social world. We are not only in a cognitive relation to things which we can modify in instrumental action, but we are always somehow already situated in a social setting in which one complies with social conventions. Heidegger detects a certain contamination of conceptions of the social world as a result of the Cartesian epistemological story:

Because the subject is conceived of, as it were, as having its being-amidst (Sein-bei) ... cut out, as a kind of torso-subject, the question concerning being-with-one-another (Miteinandersein) and its nature goes astray. Since both subjects are underdetermined, more has to be done for mediation to take place between the two than what is necessary according to their nature. The underdetermination of subjectivity causes an underdetermination of the subject-to-subject relationship. This is because now one has two subjects - although at first in such a way that no 
communication is possible - and the problem becomes one of how to bring the two torsosubjects back together.

(Heidegger, 2001a [1928-9]: 140, emphasis added) $)^{30}$

Evidently, social philosophy harbors many approaches which depart from a very abstract, isolated individual, looking out from the window of his or her perceptual house, without really reaching other individuals in their houses, figuratively speaking. In Heidegger's time, Dilthey's notion of empathy ('Einfühlung') was current and, although used in a slightly different way, this was also Husserl's way of 'curing' individuals' isolation. This approach, however, presupposes what is to be explained. According to Heidegger, the idea of 'Einfühlung' is just one of the many answers to pseudo-problems arising out of the subject/world divide, under which the problem of intersubjectivity also falls:

Enormous effort is put into shrewd theories and arguments in an attempt to explain the relationship [between the two torso-subjects] without even establishing the basic conditions which are supposed to lead to the problem. One is therefore concerned with problems that do not even exist and one does not see the problems that follow once one does not discard trivialities, but seizes upon them.

(Heidegger, 2001a [1928-9]: 69, emphasis added) ${ }^{31}$

Heidegger thus makes clear that this way of thinking results in an entirely distorted ontological perspective. In our daily encounters, in contrast, but even when alone, ${ }^{32}$ it is entirely self-evident to us that we are part of a larger whole, in which other beings are essential. There is usually no problem whatsoever in relating to other individuals or in noticing how primed our thinking and behavior are as a result of this.

Dasein and Mitsein. But what or who is Dasein? We will now turn to Heidegger's analysis of human being, which he calls Dasein (being-there). He proposes two methodological ways to address the question of human being, both of which have value for sociologists: the starting point in everyday conceptions and the hermeneutical method.

There is, in Heidegger's view, no more general term than that of being. How can one make statements about an object of which one is evidently always a part? How can one question being at all if the very fact that one is uttering something already presupposes being? This questioning is not unknown to sociologists. The problem is complicated by the fact that one essential feature of Dasein, according to Heidegger, is its historicity (Heidegger, 1982: 121; 2001b [1927]: 17-19), which is a way of taking Dasein's sociohistorical situatedness into account when explaining how understanding is established.

What does Heidegger say about the ontology of human beings? Being human is called Dasein, and is existential in nature, ${ }^{33}$ which refers to relations between Dasein and something else. This is contrasted with non-human being, which is called 'kategorial.' For Heidegger it seems to be self-evident that the understanding of being we have 'always already,' from which investigation sets out, is our everyday conception of it. It is our practical life and experiences which are the starting point, not a world independent of us 
(Heidegger, 2001b [1927]: 83-84). To show this, Heidegger confronts us with the most common everyday setting, a craftsman's workshop, an example he uses in order to describe Dasein's relations to two ways of non-human - kategorial - ways of being: (1) the 'ready-to-hand' or zuhanden (now more usually translated simply as 'available'), which refers to objects that are - literally - manipulable: it is a form of practical usefulness which cannot be identified by pure theoretical observation (Heidegger, 2001b [1927]: 69); and (2) the 'present-at-hand' or vorhanden (also often translated as 'occurrent'), which refers to what exists, but which is not 'used' in a direct sense: what is traditionally meant by nature is an example of this. The distinction between the zuhanden and the vorhanden establishes a crucial point. In contrast to ordinary approaches, in which the world is out there 'as it is,' often including man, Heidegger starts with man, or rather Dasein, who conditions 'the world' in two steps, first in terms of what is ready-to-hand - that is, in terms of what one does and relations with such 'objects' - and only indirectly through the ready-to-hand-relationship, the 'outer world,' which is present-at-hand. Heidegger, in other words, turns the normal objectivist logic around by starting with man (Dasein) and his daily practices instead of with the outer world. Insofar as he makes explicit what Dasein is through its actions in the world, and not through its conscience, one can speak of Heidegger's analysis as being pragmatic.

The second point is that the 'world,' which, so to speak, begins with what is closest to us, is not made up of isolated things and objects, but a 'whole' of relations between different tools or equipment (Zeug), signs and activities, called the Bewandtnisganzheit, of which Dasein is constitutive. ${ }^{34}$ Signs, activities, and tools are related to one another, and get their meaning in relation to one another, but ultimately by being connected and 'turned' to Dasein ('facing him'). The driving of the tractor is related to the mower that can be attached to the tractor, to the grass that is cut so that the number of mosquitoes will diminish around the house, as well as to the driver of the tractor and ultimately his wellbeing and that of others. It is this 'relational' system of tools, which of course can vary empirically, which is the ontological structure (also referred to as the 'care structure') of which man is both condition and part. It is, says Heidegger (2001b [1927]: 84), this whole that is prior to the parts that make it up. This leaves us with the question of the other(s): who are they and what is their role in the ontological edifice?

We have seen how man is 'living in the world,' but it is of course so for all men; in other words, these are not different worlds, but the same one. Dasein, Heidegger argues, is always already in the world together with other Daseins (Mitsein). Since Heidegger starts out with man (Dasein) living in the world, the question of the existence of other people does not even arise - instead, what is at issue is an existential (relation) of Dasein. Heidegger thereby rejects methodological individualism and sees 'the social context as the ultimate foundation of intelligibility' (Dreyfus, 1991: 7). Other Daseins - relations with whom are designated Mitsein - represent an existential; they are there, and Dasein's being - and, it follows, actions - are essentially bound up with them.

We can thus say that one is never alone. Although, for example, stones and the sea are also part of the 'world,' Dasein or man cannot be with them, but only with others (Mitsein), which is a special ontological relationship (an existential relationship) that characterizes Dasein (Heidegger, 2001b [1927]: 137). The relationship to others does not have to be concrete, like talking to another person face to face or on the phone; it is often 
indirect, for example in the form of 'social institutions,' such as how to speak, how to feel, and so on, which are taken over from previous generations and other persons in social interaction. Heidegger uses the notion of the Man to cover such indirect relations to others. 'Social' institutions - although, given Heidegger's terminology, 'social' is a rather meaningless prefix - are essentially part of the lifeworld which cannot be bracketed (in the Husserlian sense) or escaped. They are, thus, an essential aspect of being. One eats as one (das Man) eats, one behaves as one (das Man) behaves, and so on. These norms and activities can never be excluded from how Dasein acts; if they were, man would no longer be man. Dasein is in-the-world (Heidegger, 2001a [1928-9]: 138), involved in activities with others, for others, in the position of others, and with tools and knowledge generated by others, and in these doings, even when involved in deviant behavior, is oriented to social norms. ${ }^{35}$ This ontological constitution is 'social,' using sociological concepts to denote what Heidegger is describing. We call this ontological constitution 'socio-ontology.'

Heidegger offers a solution to both shortcomings of atomistic conceptions: Dasein is essentially in the world, and others are inseparably in this world. His main thrust is to mobilize our everyday conception of the world, including other persons, which simply does not fit in with the problems an individualistic ontology would deal with. Therefore, it is legitimate to describe many of the problems that modern philosophical theories address as pseudo-problems. ${ }^{36}$

\section{Conclusion}

Sociology inherited from tradition the assumption of basically atomistic individuals. It came upon its classics from a Cartesian malposition via economics and persists even in the self-claimed most relational approaches of today's sociology. One way to remedy this is to look at other disciplines and, as practiced in this journal, classical authors, such as Heidegger in this case. As it came out, Heidegger's starting point for a social ontology is not the isolated individual but Dasein, which is always socially constituted, always enmeshed in a world of practical things and other people.

Heidegger's sociological relevance is virtually unexploited. This is a first step in the direction of a larger study of the social grounding of his analysis; it is not a final text. We invite sociologists to continue this line of work. Heidegger was, like Nietzsche, critical of the ways in which man is socially imprinted. At the same time, we have seen that he was deeply concerned with the dominant Cartesian approach to the study of man, since it assumes theoretically what Heidegger 'empirically' could observe to be false: the atomistic ego.

What consequences and research follows from our analysis? A consequence of the socio-ontological perspective is that the social, as it were, is the taken-for-granted starting point. Thus, theories starting with a methodological individualistic approach, most notably rational choice theory, only represent one 'style' of reasoning among many others. Theories of individual action, or which presume this as a starting point, are mere modes of reasoning that at the most can be 'valid' under certain empirical conditions and in certain situations; their relevance does not follow from nature and is not a form of anthropological truth. Obviously, other ontically rooted theories - virtually all social 
science theories - are then only capable of reflecting ways in which being is 'acting,' but do not reflect essence of being, or, as Heidegger calls it, Dasein. They are, for short, rather modes of being social, in the profound way of which Heidegger talks. To develop this theme further is an important task that lays ahead.

Social scientists can embark on several projects. A first follow-up project could inquire where, when, and how atomistic-epistemological ideas became central in social theory. How could these ideas became a starting point of social thought and organization? Such a project would also be inspired by a Kuhnian or Rortian interest in when and why it was that certain problems came to be regarded as such and what made them dominant. A second project could focus on the claim, only sketched in this article, that many of current sociology's starting points are based upon definitions of problems which can be revealed to be pseudo-problems. There are several pseudo-problems, including the prisoners' dilemma, the problem of collective action, but also problems concerning structure-agency and micro-macro. We suggest that to study ontology is a way of dissolving problems rather that solving them. A third possibility, in contrast to this rather negatively focused approach, would be to try to set sociology on an entirely different trajectory and to offer a wholly different story about sociology and the origins of its problems. A history of ideas, almost opposed to the one suggested under the first project, could be written about the numerous failed and maybe even unheard of projects which, over the past couple of centuries, have tried to take some other starting point in social theory than the story of isolated individuals desperately trying to live together. This history of ideas might range from neo-Aristotelianism, through corporative ideas to modern revivals of virtue or value ethics. This kind of work would require a careful rewriting of the problematic history that constitutes sociology. A fourth possibility is to study Heidegger's ideas of 'action' (Gethmann, 1993: 245). This would imply a more detailed study of how actors go about doing their things, the role of routines, and how people are 'in-the-world' together with their tools (Zeug). A comparison of Heidegger's with pragmatists' action theories seems to be very fruitful to us. Further analysis of Heidegger's ideas on existence would also be interesting. What is the relationship between Kierkegaard and Heidegger? We point towards this relationship, rather than to the Heidegger-Sartre relationship, since relations to Kierkegaard and his sociological work have been less researched. There are of course many additional fields for study, to which we can only point, including Heidegger's ideas about language, his notion of care (Sorge) and substituting for others, and his views on technology. Taken together, the importance of fresh studies of Heidegger - and of philosophy in general - by social scientists is evident in order to avoid the historical constraints on sociological reasoning that we have described.

\section{Notes}

We are grateful to the four anonymous reviewers whose comments have helped us to improve the paper. Lars Udehn, Alexander Dobeson, as well as other participants at the Sociology Department seminar at Stockholm University have commented on this paper.

1. Though we have in mind social sciences tout court, much of our discussion focuses on sociology. This is justified not only by the addressee of this journal, but also by the fact that it is within sociology that one finds the most self-claimed non-individual approaches. If we can prove them to still be individualist, so the argument goes, it applies to other approaches as well. 
2. That sociology is not concerned with single persons reflects also in etymology. 'Social' comes from the Latin 'socius,' which means 'companion,' 'follower,' or 'ready to follow.' 'Socius' is narrower in meaning than the Greek 'politicos,' which referred to the whole community, not just a small interest group. Thomas Aquinas narrowed this original meaning when he translated it from Greek to Latin (Arendt, 1988 [1958]). Bruno Latour, like us, is critical of the way the social sciences use the notion 'social.' He suggests replacing what he sees as a substance-oriented use of 'social' (Latour, 2005). See also Latour (2005: 6) on the etymology and history of the social and socius.

3. This becomes evident, for instance, in the question of how the social emerged out of the interaction of egos, and how this world becomes ordered (Aspers, 2010a; Beckert, 2009; Empey, 1984; Gorner, 2007; Luckner, 2000; Parsons, 1968 [1937]; Wrong 1994). We find similar assumptions and formulations of problems, although often labeled 'equilibrium' in Western 'folk-psychology' (Rosenberg, 1992), including rational choice theory, and consequently in economic theory.

4. See Schmid (2005) for an extended interpretation of Heidegger's position on this point and a connection to the debate on collective intentionality.

5. Durkheim for example, sees social facts as independently existing objects to be investigated. This does not mean that he in any way solves the problem of egologism.

6. Gadamer was trying to lay a foundation of understanding, which means that he diverts from the more explicit attempts by Heidegger and, even more so, Husserl, who tried to develop methods.

7. There are of course developments of hermeneutics so that it is essentially a form of interpretation, as done by Taylor (Smith, 2004).

8. We put quotation marks around some of the notions to indicate that they represent starting points which are partly to be investigated and therefore cannot be taken for granted.

9. The historically created understanding, which we call tradition and 'knowledge,' has its roots in Greek thinking, on which later developments are built. Thus, our contemporary understanding is built on old ideas as well as taken-for-granted logical principles (Heidegger, 1994: 16-17).

10. It would require another study to find out about how Heideggerian hermeneutic themes have had an influence upon today's sociological understanding of hermeneutics: for example, via his student Gadamer.

11. There are at least two other interpretations that should be mentioned. First, it has been claimed that Heidegger's social philosophy, if its existence is granted at all, is entirely unsocial (Theunissen, 1965). According to this view, it is conceded that Heidegger talks about something like the public sphere of norms, the world of 'das Man' (' man', often translated as 'the They'), where everybody takes on socially predefined roles. From Being and Time it then becomes clear that in this sphere Dasein is in an entirely 'uneigentlich' (inauthentic) mode of being. We grant that this interpretation is possible, but it is neither the only one nor is it compatible with what Heidegger said elsewhere (see (see Heidegger, 2001a [1928-9]). This leads us to the second interpretation with regard to Heidegger's social theory, namely that there simply is no coherent social theory. We also grant this point because Heidegger, perhaps owing to his rather intuitionist mode of reasoning, certainly identifies a plethora of interesting questions and positions but without forming them into a coherent system. One can find arguments for and against central theses. But even without a complete and coherent theory of the social, some of Heidegger's ideas may reveal to be interesting and of use to sociologists.

12. See Heidegger (1978 [1928], 1979, 1998 [1934], 2001a [1928-9], 2001b [1927]; [1928/9] 2001). 
13. It is possible to make a further distinction between joint and social action. As Schmid (2005: 108ff.) points out, subjective meaning is not at all sufficient to constitute a joint action. The fact that one of two people is oriented towards another in an action setting does not make it a social action; it takes two to tango. Furthermore, subjective meaning is not even necessary for social action because one could take into account the action of others without even considering one's own contribution as being oriented to a joint project. I can take into account, for example, others' behavior on a stock market to further my own investment choices. These choices, however, are far from being a contribution to a joint project. Therefore, Weber's criterion for determining social action - that is, subjectively intended meaning - is highly doubtful as a means of capturing the essence of, and separating different, types of actions.

14. It is, according to White, 'chaos and accident' that are the 'sources and bases of identity' (1992: 4). This is an idea which White shares with Luhmann, who is well known for his Cartesian-Husserlian (egological) approach (Luhmann, 1995 [1984]).

15. Schütz combined Weber's theory of action with Husserl's theory of meaning. Although Schütz wants to ground phenomenology in the lifeworld of real people, and not in a transcendental 'lifeworld,' he nonetheless remains a faithful Husserlian egologist. Schütz says: '.. as we proceed to our study of the social world, we abandon the strictly phenomenological method. ... The object we shall be studying, therefore, is the human being who is looking at the world from within the natural attitude' (1976 [1932]: 97-98, compare 43-44). According to Schütz, the starting point of the social sciences is 'intentional conscious experiences directed toward the other self' (1976 [1932]: 144, original emphasis). Psathas (2004) has focused on the diffusion of phenomenology in American sociology. He shows that the influence of Schütz is by now widely disseminated, and that it is diffused in the works of Berger and Garfinkel, but also through the works of Psathas himself, as well as others, such as Natanson and Luckmann. Psathas, in addition, contextualizes Schütz's influence, which grew in the 1960s, and sees it in relation to a general trend of subjectivism and constructivism.

16. Husserl (2008) discussed the more social concept of lifeworld at length, most notably in his recently published text on the lifeworld.

17. See, for example, Gadamer (1990 [1960]) on the problem of intersubjectivity.

18. Other phenomenologists, such as Levinas (1987 [1947]), have tried to improve the conditions, but essentially retained the egological framework.

19. Heidegger, like all thinkers, is indebted to others. One might mention classical Greek thinkers, Kant, Nietzsche, Hegel, and Kierkegaard, to name but a few.

20. The notion of 'Volk,' which is supposed to remedy this shortcoming, is of little help because it is directly associated with an individual-independent collective entity. Moreover, it seems to be the most evident connection to a strong ethical holism associating Heidegger with the German fascist regime.

21. This critique misses the point that Heidegger (1997 [1957]), and later also Wittgenstein, is making, namely that there is no logical ground to logic.

22. It is clear that Bourdieu has read Heidegger. Bourdieu says, 'I read Heidegger, I read him a lot, and with a certain fascination ... which ... helped me a great deal ... in my efforts to analyze the ordinary experience of the social' (Robbins, 2002: 303-304).

23. Peter Berger, for example, did not find the philosophical issues to be of great interest (personal conversation between Berger and Aspers in September 2009).

24. See Koppetsch (2001) for an attempt to make explicit the Bourdieu-Heidegger connection.

25. See also Dreyfus (1991) for a discussion of the intellectual legacy of Heidegger. Giddens has not penetrated the works of Heidegger, but refers to him on time and space (Giddens 1987). Bourdieu's main work on Heidegger is to position him in the sociological field of philosophy of his time, rather than to interpret his ideas (Bourdieu, 1991 [1988]; see Weiss, 2005). 
Collins (1998) has a similar focus to that of Bourdieu. Lamont (1987) is also working in this tradition when analyzing the philosophical scene in France.

26. In English the distinction between ontic and ontological (what we are studying here) is rare. Normally, what Heidegger calls 'ontic' (beings or entities as distinct from Being) refers to the assumptions of reality that we find in sociological theories.

27. 'Die Zugangs- und Auslegungsart muß vielmehr dergestalt gewählt sein, daß dieses Seiende sich an ihm selbst von ihm selbst her zeigen kann. Und zwar soll sie das Seiende in dem zeigen, wie es zunächst und zumeist ist, in seiner durchschnittlichen Alltäglichkeit' (Heidegger, 2001b [1927]: 16) [Our translation: 'The mode of access and interpretation should be chosen as to make this being [Dasein] reveal itself. That is, it shall show the being in the state it primarily and usually finds itself, in its average-like everyday-ness.']

28. What follows for epistemology from this rather uncommon understanding of truth does not concern us here and does not detain Heidegger too long. See Tugendhat (1967) for a discussion of Heidegger's notion of truth.

29. It is clear that this starting point, like any true starting point, is not, nor can it be, grounded in reasoning (since this would then have to be assumed). Heidegger (1997 [1957]) has addressed this issue. We could add that Heidegger, in contrast to Husserl, who wants to bracket the lifeworld (Lebenswelt) to gain access to the undiluted phenomena, suggests the method of transcendental reduction to enable ego to get to the level of Descartes' pure thinking ego.

30. Our translation, see the original:

Weil nun aber das Subjekt gleichsam beschnitten um dieses Sein bei ... gedacht wird, ein Rumpfsubjekt, kommt auch die Frage nach dem Miteinandersein und dessen Wesen auf eine verkehrte Bahn. Weil beide Subjekte unterbestimmt sind, muß gleichsam für die Vermittlung beider eine reichere Veranstaltung getroffen werden, als dem Wesen nach notwendig ist. Die Unterbestimmung der Subjektivität verursacht eine Unterbestimmung der Beziehung von Subjekt zu Subjekt. Denn jetzt hat man zwei Subjekte - aber zunächst so, daß noch keine Kommunikation möglich ist - und orientiert das Problem darauf, wie diese beiden Rumpfsubjekte zusammenkommen.

31. Our translation of the original:

Mit einem ungeheuren Aufwand von scharfsinnigen Theorien und Argumenten wird diese Beziehung zu erklären gesucht, ohne daß man zuerst den Tatbestand gesichert hat, der zum Problem werden soll. Man bemüht sich also um Probleme, die gar nicht existieren, und sieht nicht diejenigen, die sich ergeben, wenn man die Trivialität nicht beseitigt, sondern sie ausschöpft.

(Heidegger, 2001a [1928-9]: 69)

32. Or, in Heidegger's words:

To be alone is in no way identical with others not existing. To be alone always means: being without others. In this being without others is, whoever is alone, necessarily and essentially, though in a specific sense, related to others. To be alone can refer to: (1) being abandoned by others, (2) being unaffected by others, (3) the lack of need for others. This means: to be alone is to be without one another; to be without one another is just a specific way of being with one another. Thus, each being alone is a being with one another, being with one another is identical to the actual with-being of others' [our translation].

(Heidegger, 2001a [1928-9]: 117-118) 
33. By this notion Heidegger means something rather different from the existentialisms of Kierkegaard or Sartre.

34. Bewandtnisganzheit is hard to translate. It refers to the totality of 'things' as they are. Furthermore, it makes no sense talking about this totality without man.

35. One example is so-called 'anti-fashion,' which refers to people who consciously try to avoid what is in fashion, and thus are as closely oriented to it as the fashion victims they criticize. Both activities are inherently 'social.'

36. There is a parallel thought in Strawson's (2005 [1959]: Ch. 3) account of descriptive metaphysics. In inquiring about the conceptual scheme necessary for identifying things talked about, Strawson equally rejects a Cartesian dualism about subjects. The idea of a purely mental subject wouldn't allow for the identification of other subjects because we could not account for their mental states being tied to one physical body. A Cartesian subject, unsure about other subjects, couldn't use the same predicates for itself and a different person, such as 'I have pain,' 'he has pain.' Apparently, this contradicts using the same predicates for more than one person. Strawson therefore rejects the Cartesian subject also on the grounds that one cannot deduce from it many practices of our social world.

\section{References}

Adorno TW (1992 [1964]) Jargon der Eigentlichkeit: zur deutschen Ideologie. Frankfurt am Main: Suhrkamp.

Aikin S (2006) Pragmatism, naturalism, and phenomenology. Human Studies 29: 317-340.

Arendt H (1988 [1958]) The Human Condition. Chicago: University of Chicago Press.

Aspers P (2009) Empirical Phenomenology: A Qualitative Research Approach (The Cologne Seminars). In: Indo-Pacific Journal of Phenomenology 9, 1-12.

Aspers P (2010a) Orderly Fashion: A Sociology of Markets. Princeton: Princeton University Press. Aspers P (2010b) The Second Road to Phenomenological Sociology. In: Society 47, 214-219.

Becker G and Murphy K (2000) Social Economics: Market Behavior in a Social Environment. Cambridge, MA: The Belknap Press of Harvard University Press.

Beckert J (2009) The social order of markets. Theory and Society 38: 245-269.

Bourdieu P (1987) What makes a social class? On the theoretical and practical existence of groups. Berkeley Journal of Sociology 22: 1-17.

Bourdieu P (1990 [1980]). The Logic of Practice. Cambridge: Polity.

Bourdieu P (1991 [1988]) The Political Ontology of Martin Heidegger. Cambridge: Polity Press.

Calhoun C, Gerteis J, Moody J, Pfaff S, and Virk I (eds) (2007) Classical Sociological Theory. Oxford: Blackwell.

Carnap R (1931) Überwindung der Metaphysik durch logische Analyse der Sprache. Erkenntnis 2: $219-241$.

Collins R (1998) A Global Theory of Intellectual Change. Cambridge, MA: Harvard University Press.

Dreyfus H (1991) Being-in-the-World: A Commentary on Heidegger's Being and Time, Division 1. Cambridge, MA: MIT Press.

Emirbayer M (1997) Manifesto for a relational sociology. American Journal of Sociology 103: 281-317.

Empey L (1984) How is social order possible? Sociological Perspectives 27: 259-280.

Fischer A (2008) Martin Heidegger - Der Gottlose Priester. Psychogramm eines Denkers. Zurich: Rüffer \& Rub.

Gadamer H-G (1990 [1960]) Wahrheit und Methode. Grundzüge einer philosophischen Hermeneutik. Band 1: Hermeneutik. Tübingen: J.C.B. Mohr.

Gadamer H-G (1993) Wahrheit und Methode. Ergänzungen, Register. Band 2: Hermeneutik II. Tübingen: J.C.B. Mohr. 
Gethmann CF (1993) Dasein: Erkennen und Handeln Heidegger im phänomenologischen Kontext. Berlin/New York: Walter de Gruyter.

Giddens A (1984) The Constitution of Society: Outline of the Theory of Structuration. Berkeley: University of California Press.

Giddens A (1987) Social Theory and Modern Sociology. Cambridge: Polity.

Gorner P (2007) Heidegger's Being and Time: An Introduction. Cambridge: Cambridge University Press.

Granovetter M (1985) Economic action and social structure: The problem of embeddedness. American Journal of Sociology 91: 481-510.

Guignon CB (2003) Heidegger, der amerikanische Pragmatismus und die Analytische Philosophie. Heidegger - gegen die Erkenntnistheorie ins Feld geführt. In: Thoma D (ed.) Heidegger Handbuch: Leben, Werk, Wirkung. Stuttgart: J.B. Metzler, 458-468.

Gutting G (2003) Michael Foucault: A user's manual. In: Gutting G (ed.) The Cambridge Companion to Foucault. Cambridge: Cambridge University Press, 49-73.

Habermas J (1984 [1981]) Theory of Communicative Action. Volume One: Reason and the Rationalization of Society. Cambridge: Polity.

Habermas J (1987 [1981]) Theory of Communicative Action. Volume Two: The Critique of Functionalist Reason. Cambridge: Polity.

Heidegger M (1975) Die Grundprobleme der Phänomenologie. Gesamtausgabe, II. Abteilung: Vorlesungen 1923-1944, Band 24. Frankfurt am Main: Vittorio Klostermann.

Heidegger M (1978 [1928]) Metaphysische Anfangsgründe der Logik im Ausgang von Leibniz. Gesamtausgabe. Band 26. Frankfurt am Main: Vittorio Klostermann.

Heidegger M (1979) Prolegomena zur Geschichte des Zeitbegriffs. Gesamtausgabe, II. Abteilung: Vorlesungen 1923-1944, Band 20. Frankfurt am Main: Vittorio Klostermann.

Heidegger M (1982) Vom Wesen der menschlichen Freiheit. Gesamtausgabe, II. Abteilung: Vorlesungen 1923-1944, Band 31. Frankfurt am Main: Vittorio Klostermann.

Heidegger M (1994) Einführung in die phänomenologische Forschung. Gesamtausgabe, II. Abteilung: Vorlesungen 1919-1944, Band 17. Frankfurt am Main: Vittorio Klostermann.

Heidegger M (1997 [1957]) Der Satz vom Grund. Gesamtausgabe, I. Abteilung: Veröffentliche Schriften 1910-1976, Band 10. Frankfurt am Main: Vittorio Klostermann.

Heidegger M (1998 [1934]) Logik als die Frage nach dem Wesen der Sprache. Frankfurt am Main: Vittorio Klostermann.

Heidegger M (2001a [1928-9]) Einleitung in die Philosophie. Gesamtausgabe, Band 27. Frankfurt am Main: Vittorio Klostermann.

Heidegger M (2001b [1927]) Sein und Zeit. Tübingen: Max Niemeyer Verlag.

Hirschman AO (1986 [1982]) Rival Views of Market Society and Other Recent Essays. New York: Viking.

Husserl E (1960 [1931]) Cartesian Meditations: An Introduction to Phenomenology. The Hague: Martinus Nijhoff.

Husserl E (2008) Die Lebenswelt, Auslegungen der Vorgegebenen Welt und Ihrer Konstitution: Texte aus dem Nachlass (1916-1937), Band. XXXIX. Dordrecht: Springer.

Joas H (1993) Pragmatism and Social Theory. Chicago: University of Chicago Press.

Joas H (1997a [1992]) The Creativity of Action. Chicago: University of Chicago Press.

Joas H (1997b) Die Entstehung der Werte. Frankfurt am Main: Suhrkamp.

Koppetsch C (2001) Heidegger und die Theorie der Praxis. In: Weiss J (ed.) Die Jemeinigkeit des Mitseins. Die Daseinsanalyse Martin Heideggers und die Kritik der soziologischen Vernunft. Konstanz: UVK Verlagsgesellschaft, 345-370.

Lamont M (1987) How to become a dominant French philosopher: The case of Jacques Derrida. The American Journal of Sociology 93: 584-622. 
Latour B (2005) Reassembling the Social: An Introduction to Actor Network Theory. Oxford: Oxford University Press.

Levinas E (1987 [1947]) Time and the Other. Pittsburgh: Duquesne University Press.

Luckner A (2000) Martin Heidegger: 'Sein und Zeit', Ein einführender Kommentar. Paderborn: Ferdinand Schöningh.

Luhmann N (1995 [1984]) Social Systems. Stanford, CA: Stanford University Press.

Malhotra V (1987) A comparison of Mead's 'self' and Heidegger's 'Dasein': Toward a regrounding of social psychology. Human Studies 10: 357-382.

Olson M (1971 [1965]) The Logic of Collective Action, Public Goods and the Theory of Groups. Cambridge, MA: Harvard University Press.

Parsons T (1968 [1937]) The Structure of Social Action. New York: Free Press.

Psathas G (2004) Alfred Schütz's influence on American sociologists and sociology. Human Studies 27(1): 1-35.

Robbins D (2002) Sociology and philosophy in the work of Pierre Bourdieu, 1965-75. Journal of Classical Sociology 2: 299-328.

Rosenberg A (1992) Economics: Mathematical Politics or Science of Diminishing Returns? Chicago: University of Chicago Press.

Schmid HB (2003) Heidegger und die Sozialwissenschaften. Verabschiedung, Vereinnahmung und vorsichtige Anneigung. In: Thoma D (ed.) Heidegger Handbuch: Leben, Werk, Wirkung. Stuttgart: J.B. Metzler, 481-486.

Schmid HB (2005) Wir-Intentionalität. Kritik des ontologischen Individualismus und Rekonstruktion der Gemeinschaft. Freiburg/Munich: Verlag Karl Alber.

Schmid HB (2009) Plural Action: Essays in Philosophy and Social Science. New York: Springer.

Schütz A (1976 [1932]) The Phenomenology of the Social World. London: Heinemann Educational Books.

Schütz A (1996) Collected Papers IV. Dordrecht: Kluwer Academic.

Sluga H (2003) Foucault's encounter with Heidegger and Nietzsche. In: Gutting (ed.) The Cambridge Companion to Foucault. Cambridge: Cambridge University Press, 210-239.

Smith NH (2004) Taylor and the hermeneutic tradition. In: Abbey R (ed.) Charles Taylor. Cambridge: Cambridge University Press, 29-51.

Steel V (ed.) (2004) Encyclopedia of Clothing and Fashion. New York: Charles Scribner's Sons.

Strawson PF (2005 [1959]) Individuals: An Essay in Descriptive Metaphysics. London/New York: Routledge.

Swedberg R (1998) Max Weber and the Idea of Economic Sociology. Princeton, NJ: Princeton University Press.

Swedberg R (2011) Thinking and sociology. Journal of Classical Sociology 11: 31-49.

Theunissen M (1965) Der Andere. Studien zur Sozialontologie der Gegenwart. Berlin: de Gruyter.

Tugendhat E (1967) Der Wahrheitsbegriff bei Husserl und Heidegger. Berlin: de Gruyter.

Udehn L (2002) Methodological Individualism: Background, History and Meaning. London: Routledge.

Walsh A and Giulianotti R (2007) Ethics, Money and Sport: This Sporting Mammon. London: Routledge.

Weber M (1978 [1921-2]) Economy and Society: An Outline of Interpretive Sociology. Berkeley: University of California Press.

Weiss J (2001) Einleitung. In: Weiss J (ed.) Die Jemeinigkeit des Mitseins. Die Daseinsanalytik Martin Heideggers und die Kritik der soziologischen Vernunft. Konstanz: Verlagsgesellschaft $\mathrm{mbH}, 11-56$.

Weiss J (2005) Von innen nach außen. Über Bourdieus Heidegger-Lektüre. In: Interdisziplinäre Arbeitsgruppe Kulturforschung (ed.) Intervalle 8, Schriften zur Kulturforschung. Kassel: Universität Kassel. 
White H (1992) Identity and Control: A Structural Theory of Social Action. Princeton, NJ: Princeton University Press.

White H (2008) Identity and Control: How Social Formations Emerge. Princeton, NJ: Princeton University Press.

Wrong D (1994) The Problem of Order: What Unities and Divides Society. New York: Free Press.

\section{Author biographies}

Patrik Aspers is Professor of Sociology at the Department of Sociology, Uppsala University. He has written on economic sociology and sociological theory. Aspers has previously published on classic thinkers, such as Alfred Marshall, Vilfredo Pareto, and Friedrich Nietzsche. In 2011 he published the book Markets (Polity).

Sebastian Kohl is a doctoral fellow at the Max Planck Institute for the Study of Societies. His research interests lie in the domain of economic sociology and philosophy of the social sciences. $\mathrm{He}$ is currently working on a thesis that explains housing market differences across industrialized nations with reference to different historical institutional set-ups. 